\title{
KEBERHASILAN PROSES PENDIDIKAN KARAKTER TERDAPAT DI PUNDAK PENDIDIKNYA
}

\author{
Oleh : \\ Putu Subawa \\ Dosen Fakultas Dharma Acarya IHDN Denpasar
}

\begin{abstract}
Educators important figure in character education course caused by its presence as a central figure in education. Good educator of character is when he does not care about him as long as he could see their students grow and thrive. Character educators on assessed from nature sincere, patient, and full commitment to establish soul didiknya.Peningkatan welfare participants would not quite able to change the quality of teachers and education if it is not accompanied by changes in educational culture and spirit of education. Increased prosperity will not be quite capable of changing the quality of teachers and education if it is not accompanied by changes in educational culture and spirit of education. Personality and character pendidiki must be strong so that he was not brought on by a situation that makes his personality defeated by circumstances. Strong personality and unwavering needed to create a role that also serves to form the personality of learners. Progressive educator is an educator who serves as a motivator. Its function is to make students believe that they can change, they are engaged and motivated that the learning process gives them the understanding and skills which can make the face of the world.
\end{abstract}

Keywords: educator, character education

\section{PENDAHULUAN}

Sosok penting pendidik dalam pendidikan karakter tentu saja disebabkan oleh keberadaannya sebagai figur sentral dalam pendidikan. Pendidik adalah orang yang bertanggung jawab dalam proses belajar mengajar, memiliki ruang untuk dikondisikan dan diarahkan, yaitu ruang kelas tempat ia dan murid-muridnya (peserta didik) berinteraksi. Meski sekarang ia muncul acuan-acuan pengajaran yang harus diikuti untuk memandu proses pendidikan dan pengajaran, penulis kira wewenang dan otoritas pendidik di dalam kelas masihlah sangat besar. Keberadaan otoritas inilah yang selalu menjadi penentu arah perkembangan karakter anak. Ketika otoritas digunakan dengan sebaik-baiknya untuk bertindak maksimal dalam membuat tindakan kelas (class action) kondusif bagi perkembangan kedewasaan dan kecerdasan anak, itu akan membuat peran pendidik benarbenar maksimal. Akan tetapi, jika otoritas itu disalahgunakan, kadang akan terjadi tindakan yang tidak kondusif bagi perkembangan peserta didik, tetapi bahkan akan membuat citra pendidik terpuruk apabila jika tindakan menyimpang tersebut terekspos ke media massa dan terpublikasikan ke masyarakat, sosok pendidik tersebut tiba-tiba menjadi bangkrut di mata orang lain.

Kejadian semacam itu akhir-akhir ini tak jarang kita lihat, saat keterbukaan informasi mulai terjadi. Seperti yang pernah terjadi di media, karena ingin memperoleh hasil (nilai) 
yang baik sekelompok pesrta didik secara bersama-sama (masal) melakukan kecurangan dalam suatu proses Evaluasi (baca; ujian), sehingga beribu mata melihat melalui media inforrmasi tersebut. Nyontek Masal, demikian judul berita yang tersebar. Demikian juga dalam kasus yang lain, misalnya yang sering terjadi adalah melakukan kekerasan pada murid, juga tindakan pencabulan ( prilaku asusila) dimana seorang pendidik yang menjadi pelakunya. Halhal seperti ini adalah sebagian contoh dimana sosok pendidik memiliki nilai negative dan menjadi sorotan dari masyarakat

Data lainnya menyatakan adalah data UNESCO (2000) tentang peringkat Indeks Pengembangan Manusia (Human Development Index), yaitu komposisi dari peringkat pencapaian pendidikan, kesehatan, dan penghasilan per kepala yang menunjukkan, bahwa indeks pengembangan manusia Indonesia makin menurun. Di antara 174 negara di dunia,Indonesia menempati urutan ke-102 (1996), ke-99 (1997), ke-105 (1998), dan ke109(1999). Menurut survei Political and Economic Risk Consultant (PERC), kualitas pendidikan di Indonesia berada pada urutan ke-12 dari 12 negara di Asia. Posisi Indonesia berada di bawah Vietnam. Data yang dilaporkan The World Economic Forum Swedia (2000), Indonesia memiliki daya saing yang rendah, yaitu hanya menduduki urutan ke37 dari 57 negara yang disurvei di dunia. Dan masih menurut survai dari lembaga yang sama Indonesia hanya berpredikat sebagai follower bukan sebagai pemimpin teknologi dari 53 negara di dunia.

\section{PEMBAHASAN}

\subsection{Perubahan Karakter Pendidik}

Ketika membicarakan karakter pendidik, kita menganggap bahwa pendidik adalah produk perkembangan sejarah yang terus berubah. Perubahan ini dipicu oleh perkembangan wilayah material, kemajuan teknologi yang memengaruhi karakter manusia, termasuk memengaruhi karakter dari sosok pendidik. Dengan pandangan ini, kita ingin melihat bagaimana perbedaan karakter dan peran yang ada pada pendidik antara zaman dulu dan zaman sekarang. Kalau zaman dulu, pendiidik menjadi pusat segalanya, sekarang ini apa yang dulu hanya bisa diberikan oleh pendidik sudah dapat didapat di luar sosok pendidik. Misalnya, bicara pengetahuan, peserta didik tak terlalu menyadarkan pada pendidik, tetapi Google atau jenis penelusuran internet yang lainnya sudah dapat memberikannya.

Ibaratnya antara pendidik dan sosok penelusuran tersebut muali terjadi keopetisi, bila melihat hal tersebut maka peran yang sangat berbeda antara pendidik zaman dulu dan zaman sekarang. Kondisi ini memengaruhi hubungan peserta didik dengan pendidik, juga mempengaruhi citra pendidik. Misalnya, model pemahaman yang konvensional ketika pengetahuan semata-mata disandarkan pada pendidik, kewenangan dan otoritas pendidik amatlah besar. Ini karena pendidik adalah sumber pengetahuan, sumber segala arahanarahan yang harus diikuti. Hal ini dikompensasi oleh sikap peserta didik terhadap pendidik dimana pendidik benar-benar dijadikan sumber informasi oleh pendidik. Maka, pada tahap ini pendidik dipandang sebagai orang yang senantiasa diikuti petuah-petuahnya dan didengar ajaran-ajarannya karena memiliki karakter membimbing yang kuat meskipun dihiasi dengan nuansa transendental. Seorang pendidik dihormati karena mampu menjelaskan kondisi masyarakat, alamnya, atau memiliki stock of knowledge yang akan ditransfer pada anak didiknya, anak asuhnya, atau bahkan mereka yang membutuhkannya.

Karakter pendidik pada zaman dulu dinilai dari sifatnya yang tulus, sabar, dan penuh komitmen untuk membentuk jiwa peserta didiknya. Kemuliaan dan kepintaran peserta diidik adalah kebahagiaan bagi seorang 
pendidik yang sejati. Jadi, karakter pendidik yang baik adalah ketika ia tidak memedulikan dirinya selama ia bisa melihat peserta didiknya tumbuh dan berkembang. Dijaman sekarang tidak sedikit pula pendidik yang mengejar karier untuk bisa mendapatkan kedudukan, misalnya agar diangkat menjadi kepala satuan pendidikan atau kepala lembaga perguruan tingggi. Bahkan, untuk mendapatkan posisi ini, ternyata banyak diwarnai dengan permainan kekuasaan yang melibatkan tindakan-tindakan dan sikap-sikap yang tak mencerminkan karakter yang baik. Apalagi, kalau dilihat bahwa kedudukan seorang kepala adalah jabatan yang "basah" karena punya kewenangan untuk menentukan proyek pembangunan, yang membuatnya harus bermain untuk mengendalikan kepentingan untuk memperebutkan keuntungan yang didapat dari pengerjaan proyek yang berhubungan dengan politik anggaran. Memang akan dapat dilihat bagaimana pendidik zaman sekarang juga lebih banyak mengejar uang dari kegiatan mengajar dan ikut politik praktis. Dengan demikian, kearifan dari kegiatan mengajar yang diwariskan pada zaman dulu tak dapat diwariskan. Ini memang dibentuk oleh situasi sosial, ketika kuasa ekonomi yang sedang mendominasi pendidikan adalah masyrakat kapitalistik.

Lebih jauh, menjadi pendidik adalah untuk mendapatkan keuntungan. Cara berpikir ini tersistematisasikan dan terlembagakan ketika pendidikan yang terlembagakan dalam sekolahsekolah mulai bertranspormasi di bawah bimbingan kapitalisme-muncullah kapitalisme pendidikan. Misalkan pada tatanan sekolah menengah muncul istilah SBI dan RSBI adalah salah satu indicator munculnya kapitalisme dalam sector pendidikan. Dengan berkedok sekolah yang berstandar internasional maka komponen pengelola satuan pendidikan (sekolah) berlomba-lomba memungut biaya pendidikan diluar peraturan dengan berbagai alasan. Tetapi akhirnya terbukti seecara yuridis bahwa SBI dan RSBI adalah tidak sesuai dengan Undang-Undang Sistem Pendidikan Nasional (SISDIKNAS) saat ini. Sehingga, setiap ingin menghasilkan kualitas dan karakter tertentu (biasanya karakter dengan ukuran kapitalistik), harus membayar. Pendidikan menjadi sangat komersial dan mahal.

Dalam situasi semacam inilah, karakter para pendidik dibentuk. Pendidik dalam masyarakat kapitalis dan pendidikan kapitalis kehilangan semangat pengabdiannya karena dihadapkan pada situasi masyarakat dengan cekokan ideologi-ideologi pada masyarakat dan guru adalah bagian dari masyarakat. Kapitalisme menggoda masyarakat untuk hidup bergaya, rangsangan-rangsangan iklan untuk menjadi konsumtif dan meniru gaya hidup kelas super kaya. Tak jarang, para pendidik juga terpengaruh oleh ideologi tersebut. Karakter pendidik dapat dilihat dari apa yang dibicarakan dan bagaimana ia memaknai sesuatu yang bisa dilihat dari apa yang ia bicarakan. Pendidik yang tak bisa memahami anak didik itulah yang egois dan sering membuat anak-anak didik teralienasi dalam dunia sekolah sehingga sekolah tak menyenangkan dan banyak yang justru ingin lari.

\subsection{Apakah Kesejahteraan Mening- katkan Karakter Tenaga Pendidik?}

Selama ini, persoalan kualitas guru yang memburuk, baik secara penguasaan pengetahuan maupun degradasi moralnya, sesungguhnya merupakan warisan sejarah pendidikan dan situasi sosial secara umum dalam kurun sejarah yang dibentuk oleh perkembangan ekonomi-politik. Indonesiakini kualitas pendidik dan pendidikannya tertinggal jauh bukan hanya dengan Malaysia, melainkan juga dengan India, bahkan Vietnam.

Upaya meningkatkan kesejahteraan sebenarnya telah diupayakan sejak dahulu dan pemberian gaji ke tiga belas yang hingga sekarang masih dilakukan ternyata juga belum menunjukkan kualitas pendidik dan perbaikan mereka sebagai ujung tombak dalam 
pendidikan generasi bangsa. Persoalan yang masih dominan adalah bahwa pendidik masih belum memiliki kebebasan. Kesejahteraan yang diberikan juga masih terbatas dan tertinggal dibandingkan negara-negara lain.

Keluarnya Undang-Undang Sistem Pendidikan Nasional (SISDIKNAS) Nomor 20 Tahun 2003 merupakan inisiatif kalangan pemerintah untuk mencoba merespon anggaran yang diberikan Negara untuk pendidikan sebesar 20\% dimana didalamnya juga terdapat pasal yang mengatur tentang peningkatan kesejahtraan pendidik. Ini bukti bahwa pemerintah mencoba merespon suara-suara yang menyatakan bahwa peninggkatan kesejahtraan (baca; gaji) adalah indikatoor yang positif untuk meningkatkan kualitas pendidikan Nasional. Munculnya tentang peningkatan kualitas penghasilan dari pendidik mau tidak mau sangat mempengaruhi nilai tawar dari lembaga pendidikan yang mencetak tenaga kependidikan atau dengan kalimat sederhana harapan kaya dari seorang pendidik menjajikan. Inilah akhirnya orang belombalomba melanjutkan studi di perguruan tinggi yang mencetak calon pendidik atau LPTK.

Tentu saja, peningkatan kesejahteraan tak akan cukup mampu mengubah kualitas pendidik dan pendidikan jika tak dibarengi dengan perubahan budaya mendidik dan semangat pendidikan. Maka, setelah gaji mereka dianggap cukup dan tak lagi pusing untuk mencari tambahan penghasilan di luar, kini sudah saatnya mereka mulai mengabdikan dirinya secara penuh dalam bidang pendidikan, mengajar anak-anak dengan tingkat semangat yang lebih besar, dan kompetensi mengajar yang lebih kuat.

Kemudian juga masih kuatnya politik pendidikan yang mengontrol arah dan sistem pendidikan selama tiga decade membuat para pendidik seperti "robot" yang dipenjara melalui tugas-tugas kedinasan yang stagnan. Mudahmudahan dengan cukupnya gaji, guru-guru kita akan lebih mandiri, berkarakter dan tak hanya tunduk pada politik pendidikan yang menghambat kemajuan bangsa.

\subsection{Kepribadian dan Karakter yang Harus Dimiliki Tenaga Pendidik}

Kepribadian adalah hubungan antara materi tubuh dan jiwa seseorang yang perkembangannya dibentuk oleh pengalaman dan kondisi awal bawah sadar yang terbentuk sejak awal pertumbuhan manusia, terutama akibat peristiwa-peristiwa psikologis yang penting dalam pertumbuhan dirinya. Banyak yang beranggapan bahwa tidak ada orang yang memiliki dua kepribadian kecuali orang yang sakit jiwa. Kepribadian orang itu digunakan untuk merespons lingkungan sekitarnya. Bukan berarti segala tingkah laku orang ditentukan kepribadiannya, melainkan ada saat-saat tertentu lingkungan luar diri bisa mengubah kepribadian seseorang jika lingkungan itu punya pengaruh yang besar. Karena itulah, kepribadian bisa berubah jika lingkungan tibatiba berubah.

Bicara tentng kepribadian, berarti kita bagaimana sifat hakiki yang tercermin dari sikap seseorang. Jadi, kepribadian itu cerminan dari apa yang bisa kit lihat dari pikiran dan tindakannya. Kepribadian manusia selalu berkembang sehingga bisa dibentuk ulang dan diubah.

Mengapa pendidik harus memiliki kepribadian yang dibutuhkan dengan ukuranukuran tertentu? Kepribadian ini harus melekat kuat dalam diri pendidik karena pendidik diharapkan akan menjadi kaum yang mengarahkan kepribadian orang, bahkan lingkungan. Dengan demikian, kepribadian dan karakter pendidiki harus kuat agar ia tak dibawa oleh situasi yang membuat kepribadiannya kalah dengan keadaan. Kepribadian kuat dan kukuh dibutuhkan untuk menciptakan peran yang juga berfungsi membentuk kepribadian peserta didiknya. Kepribadian yang dimiliki pendidik adalah apa yang harus diteladani oleh orang lain, terutama pesrta didiknya. 


\subsection{Pendidik (Berkarakter) Progresif}

Karakter ingin maju berarti adalah karakter ingin mengubah keadaan yang dianggapnya kurang baik dan keadaan yang penuh masalah serta keadaan yang menghambat kemajuan. Karakter progresif berdasarkan analisis kritis terhadap keadaan diri dan lingkungannya. Maka, muncullah perspektif baru yang berguna untuk menegaskan pentingnya perubahan dan muncul pula alternative-alternatif untuk memecahkan masalah yang dihadapi, yaitu masalah yang harus diarahkan pada situasi yang mendukung pada kemajuan.

Kebalikan dari seorang pendidik yang progresif adalah pendidik yang konservatif. Pendidik model ini adalah pendidik yang pasrah pada keadaan, tidak mau mengubah kondisi yang ada, dan hanya menempatkan situasi yang dihadapi sebagai sesuatu yang diterima tanpa dianggap sebagai produk sosial yang bisa diubah.

Pendidik progresif percaya pada potensi pendidikan untuk perubahan dan menjadikannya untuk pengetahuan bukan untuk sekadar menjalankan pekerjaan yang menghasilkan uang. Pendidik progresif memiliki kepercayaan diri serta memiliki jiwa inofatif yang terintergrasi dalam setiap tanggung jawab yang diembannya. . Karena mencita-citakan perubahan, seorang pendidik yang progersif adalah yang harus punya kemampuan untuk mendorong, menggerakkan, dan memberi keyakinan. Maka, pendidik progresif adalah pendidik yang berfungsi sebagai motivator. Fungsinya adalah membuat anak didik yakin bahwa mereka bisa berubah, mereka bergerak dan termotivasi bahwa proses belajar memberi mereka pemahaman dan keterampilan yang bisa membuatnya menghadapi dunia.

Lembaga pendidikan harus menjadi pusapusat kreativitas, tempat orang mengajar dan belajar dengan rasa senang atau menyenangkan. Kondisi-kondisi materiil, gaji pendidik dan stafnya, pemeliharaan dan perbaikan lembaga pendidikan pada waktunya, dan tujuan pelangsingan birokrasi merupakan suatu hal yang harus dipenuhi.

Oleh karenanya, situasi menyenangkan harus diciptakan. Jika tidak, yang terjadi hanyalah ketegangan yang menciptakan perasaan bahwa interaksi edukatif itu membosankan dan bikin stressed (menekan pikiran). Jika ketegangan tercipta, hal ini akan menyebabkan kerentanan bagi psikologis peserta didik. Keberhasilan seorang pendidik adalah ketika pendidik menyampaikan pengetahuan, wawasan, dan kebenaran ilmiah, wajah anak didiknya berbinar-binar karena apa yang didengar dipahami dan pemahaman itu membuatnya yakin bahwa ilmu yang didapatnya merupakan hal yang baru yang sangat berarti. Penting untuk meyakinkan bahwa kalau kita punya pengetahuan, ia mengubah cara pandang anak didik yang lama sehinga pandangan baru itu memotivasinya untuk menilai diri sendiri dan kehidupan yang dialaminya.

Akan lebih baik lagi dan akan lebih mengena jika pengetahuan yang kita sampaikan membuatnya mengevaluasi pengetahuan lama. Dengan demikian, dia akan sadar bahwa ternyata banyak yang belum ia pahami dan pemahaman-pemahaman baru itu ternyata amatlah berguna baginya untuk menghasilkan sikap baru. Tidak menutup kemungkinan bahwa ia akan justru mencari lebih banyak lagi pengetahuan di luar yang diajarkan pendidiknya didalam kelas.

Memang seperti itulah yang diharapkan. Karena itulah, seorang pendidik yang baik itu adalah seorang inspirator dan motivator. Pendidik tidak dituntut untuk menyampaikan banyak hal apalagi terpaku banyak dengan metode-metode dan gaya mendidik yang membosankan. Sekali ini terjadi, bukan hanya peserta didik tertarik pada mata pelajaran atau mata kuliah yang disampaikan. Bahkan, bisa jadi juga akan tidak suka pada pengetahuan. 


\section{KESIMPULAN}

Bertolak dari uraian-uraian diatas, maka dapat disimpulkan hal-hal sebagai berikut.

1. Karakter pendidik yang baik adalah ketika ia tidak memedulikan dirinya selama ia bisa melihat peserta didiknya tumbuh dan berkembang. Karakter pendidik pada dinilai dari sifatnya yang tulus, sabar, dan penuh komitmen untuk membentuk jiwa peserta didiknya

2. Peningkatan kesejahteraan tak akan cukup mampu mengubah kualitas pendidik dan pendidikan jika tak dibarengi dengan perubahan budaya mendidik dan semangat pendidikan.

3. Kepribadian dan karakter pendidiki harus kuat agar ia tak dibawa oleh situasi yang membuat kepribadiannya kalah dengan keadaan. Kepribadian kuat dan kukuh dibutuhkan untuk menciptakan peran yang juga berfungsi membentuk kepribadian peserta didiknya.

4. Pendidik progresif adalah pendidik yang berfungsi sebagai motivator. Fungsinya adalah membuat anak didik yakin bahwa mereka bisa berubah, mereka bergerak dan termotivasi bahwa proses belajar memberi mereka pemahaman dan keterampilan yang bisa membuatnya menghadapi dunia.

\section{DAFTAR PUSTAKA}

Dimyati dan Mudjiono, 2006. Belajar dan Pembelajaran. Jakarta: Rineka Cipta.

Ghony, HM. Djunaedi, 2008. Penelitian Tindakan Kelas. Malang : UIN Malang Press.

Martinis, 2001. Metode Pembelajaran yang Berhasil, Jakarta. Penerbit Sesama Mitra Suksesa
Muchith, M. Saekhan, 2008. Pembelajaran Kontekstual. Semarang : Rasail.

Mulyasa, 2005. Implementasi Kurikulum 2004 Panduan Belajar KBK, Bandung. Remaja Rosdakarya

Pidarta, Made, 2000. Landasan Pendidikan : Stimulus Ilmu Pendidikan Bercorak Indonesia. Jakarta : Rineka Cipta.

Silabus KTSP Kurikulum Tingkat Satuan Pendidikan Agama Hindu dan Model

Silabus untuk Sekolah Dasar. Dirjen Bimas Hindu-Surabaya: Paramita.

Subagyo, P. Joko, 2004. Metode Penelitian Dalam Teori Dan Praktek. Jakarta: PT. Rineka Cipta.

Sukmadinata, Nana Syaodih, 2007. Pengembangan kurikulum Teori dan Praktek. Bandung: remaja Rosdakarya. Suryabrata, Sumadi, 2001. Psikologi Pendidikan. Jakarta: Rajagrafindo.

Susilo, 2007. Panduan Penelitian Tindakan Kelas. Yogyakarta: Pustaka Book Publisher.

Syukur, Fatah, 2005. Teknologi Pendidikan. Semarang: Rasail.

Thoha, Miftah, 2005. Prilaku Organisasi Konsep Dasar dan Aplikasinya. Jakarta:

Raja Grafido.

Uno, Hamsah B, 2007. Model Pembelajaran Menciptakan Proses Belajar Mengajar

Yang Kreatifdan Efektif. Jakarta: Bumu Aksara.

Undang-Undang R.I Nomor 20 Tahun 2003 tentang Sistem Pendidikan Nasional. Jakarta: Departemen Pendidikan Nasional. 